\title{
Misliti medkulturno literarno zgodovino na Slovenskem
}

\author{
Anja Skapin
}

Rožna dolina cesta XIX 7a, 1000 Ljubljana

https://orcid.org/0000-0003-2701-5897

anja.skapin@gmail.com

\begin{abstract}
Razprava obravnava medkulturnost kot problematiko literatur v intra-in intersubjektivnem ter v intra-in interdiskurzivnem stiku, obenem pa osvetjuje nekatere možnosti za nadgradnjo slovenske literarne zgodovine in kanona. Osredotoča se na čas po osamosvojitvi, ko se je po eni strani povečalo zanimanje za raziskovanje preteklosti, po drugi strani pa so se že začele kazati smernice homogeno usmerjenega knjižnega (globalnega) trga. Slovenija se je po osamosvojitvi še vedno soočala z dvema prelomnicama: kako ohranjati lastno identiteto, kar je bilo takrat prvič pousem v rokah državne avtonomnosti; in kako poskrbeti za identiteto ter prepoznavnost malega naroda in male književnosti po padcu v hitro rastoči globalni knjižni trg. Na podlagi modela medkulturne literarne vede lahko vidimo, kako se lastno in tuje prepletata na vseh ravneh človekovega delovanja in posledično delovanja družbe ter kakšen vpliv ima to na izgradnjo dinamične identitete in dinamičnega literarnega kanona.
\end{abstract}

Ključne besede: literarna zgodovina / medkulturnost / literarni kanon / kulturni spomin / kulturna identiteta / tujost / tradicija / globalizacija

Literarna zgodovina ima tudi po osamosvojitvi funkcijo krepitve kulturnega spomina. ${ }^{1}$ A namen pričujoče razprave ne bo iskanje referenčne funkcije literature kot narodotvornega sredstva (kar je bila redna praksa preteklih obdobij), temveč v utemeljevanju medkulturnosti, ki bi lahko slovenskemu prostoru ponudila jasnejšo sliko o identiteti in kulturnem spominu, s tem ko bi v razlikah vnovič našla sebe. Nadgradnja nacionalne literarne zgodovine $\mathrm{z}$ medkulturno perspektivo bi lahko poleg družbeno-kulturnih razmer in svoje povezave $\mathrm{z}$ literarno tradicijo raziskovala predvsem svoj osrednji predmet, tj. literaturo v njeni dinamični identiteti. Dinamične identitete pa ne gre misliti brez razmerja lastno/ tuje, ki predstavlja osrednji delovalni princip, ki ga bomo aplicirali

${ }^{1}$ Razprava je nastala v okviru raziskovalnega projekta "Slovenska literatura in družbene spremembe: nacionalna država, demokratizacija in tranzicijska navzkrižja» (J6-8259), ki ga sofinancira ARRS. 
na tri dvojice: spomin/pozaba, center/periferija, lokalno/globalno. Medkulturno literarno vedo bomo ponazorili na podlagi modela, ki obravnava medkulturnost na različnih ravneh delovanja: intrasubjektivnost (spomin, pisanje), intersubjektivnost (pripovedovanje), intradiskurzivnost (notranja dinamika kulture in kolektivni spomin; notranje delovanje slovenskega literarnega sistema), interdiskurzivnost (slovenska književnost in njeno razmerje do globalnega knjižnega trga). Videli bomo, da se vse plasti med seboj prepletajo in prehajajo druga $\mathrm{v}$ drugo. Vsem ravnem je namreč skupno to, da se odpirajo iz določene tradicije (naj bo to vpetost subjekta $\mathrm{v}$ zgodovinskost, kolektivni spomin ali pa literarni kanon), kar ni pomembno le za izgradnjo dinamične identitete, temveč tudi za omilitev kontingence in presežka smisla v hitro rastočem korpusu (globalne) književnosti.

Začeli bomo $\mathrm{z}$ razmerjem lastno/tuje, ki predstavlja najmanjšo enoto dinamičnega delovanja znotraj določene kulture. Ko se ukvarjamo $s$ fenomenom tujosti, stoji $\mathrm{v}$ središču pogled na tuje, ki izhaja iz subjekta samega (iz njegovega sebstva), saj so strahovi, predsodki, nelagodja ob izkustvu tujega zgolj v nas samih. Tuje torej ni dojeto kot identiteta oziroma lastnost drugega, temveč kot druga stran razlike, drugi pol binarne dvojice lastno/tuje. Tujost ni niti kulturno niti geografsko pogojena, temveč se v našem primeru kaže kot gola oblika relacije, zato se bomo tudi $\mathrm{v}$ tej razpravi osredotočali na samo relacijo lastno/tuje in ne toliko na družbene, kulturne, etične in podobe razlike, saj lahko katerikoli odnos lastno/tuje analiziramo v kontekstu vsakokratnih družbenih pojavov in sprememb. Zato tudi medkulturnosti ne obravnavamo v luči kulturnih razlik in njihovega posredovanja, temveč jo razumemo kot sredstvo za ponovno vzpostavitev tistega temelja, ki pomeni posredovanje med lastnim in tujim - se ne polašča tujega zgolj zaradi samopotrjevanja in ne zatira tujega zaradi obrambe lastnega. Medkulturnost po nemškem fenomenologu Bernhardu Waldenfelsu ${ }^{2}$ pomeni delovanje in mišljenje $\mathrm{v}$ smeri iskanja novih rešitev in odgovorov v občevanju s tujim. Medkulturnost kot model razumevanja tujega lahko v povezavi z literarno vedo razumemo kot radikalnokonstruktivistično refleksijo, katere funkcija ni več iskanje univerzalnega smisla, temveč iskanje možnega. $\mathrm{Z}$ radikalnim konstruktivizmom se literarnemu sistemu določi tri družbene funkcije: spoznavno-refleksivno, moralno-družbeno in hedonistično. Vendar pa ima literarni sistem še

${ }^{2}$ Vprašanje, ki si ga Waldenfels zastavlja, je: "Se tuje razrešuje na tleh hermenevtike ali pa je tuje prikladno ravno zato, da postavlja pod vprašaj samo hermenevtiko?» (Waldenfels, Vielstimmigkeit 67). Kot odgovor na to razvije koncept radikalne tujosti, saj lahko le z njo presežemo meje hermenevtike in jo postavimo pod vprašaj. 
eno pomembno funkcijo, in sicer estetsko-avtonomno, ki ne dopušča instrumentalizacije literarnega besedila, saj je besedilo v prvi vrsti znakovna struktura. $\mathrm{Pa}$ ima literatura dandanes sploh še lahko vrednost sama po sebi?

$\mathrm{V}$ nadaljevanju bomo pogledali, kako se je spreminjal odnos do literature, in sicer $s$ prehodom iz družbeno-ideološke $\mathrm{v}$ proizvodnoporabniško funkcijo literature, kjer bo $\mathrm{v}$ ospredju vprašanje kanona. Homogenizacija družbe temelji na določenih vrednotah, ki postanejo del kolektivne zavesti in okoli katere se tudi zgradi identiteta določene nacije. To je bilo še posebej izrazito v odnosu pisatelja do družbe (in obratno), kar je tipološko nazorno razdelal Marijan Dović v monografiji Slovenski pisatelj (2007). Po Doviću je zadnji, še vedno aktualni tip literarnega proizvajalca v slovenskem literarnem prostoru "pisatelj med umetnikom in proizvajalcem ", ki kaže na razpetost med avtonomnostjo literature in zahtevami oziroma povpraševanjem globalnega trga. Zato je v času globalizacije, ki je že v svoji osnovi zelo razpršen pojem, še toliko bolj pomembno, da reflektiramo razmerje lastno/tuje, sploh v povezavi s kolektivnim spominom.

Če se vrnemo k dinamični identiteti, naj apliciramo razmerje lastno/ tuje na razmerje tradicija/inovacija, iz česar sledi, da vselej izhajamo iz lastne tradicije. To pomeni, da je naše razumevanje zaznamovano tako $s$ tradicijo kot z zgodovinskostjo (naše razumevanje je odvisno od časa, $v$ katerem živimo). V nasprotju s tradicionalno hermenevtiko Waldenfels napeljuje na to, naj se naučimo živeti s tujim, ne da si ga skušamo prilastiti. Njegova kritika logocentrizma govori tudi v prid dekonstrukciji, saj njegovo poudarjanje radikalno tujega meri na to, da tuje v logocentrizmu sploh nima svojega mesta. Za razumevanje medkulturnosti je najprej potrebna jasna predstava o lastni kulturi (samorefleksija), nato pa še zamenjava tradicionalne hermenevtike z medkulturno hermenevtiko, ki prinaša boljše zavedanje o kompleksnosti pojmovnega sveta. To pa potegne za sabo tudi pojem zgodovinskosti. Waldenfels se sprašuje, iz česa zgodovinskost pravzaprav sestoji in kje je njen izvor; ali obstaja zgodovina spoznavnosti ali zgolj zgodovina različnih perspektiv; in ali to pomeni, da isto zadevo zgolj drugače vidimo, ali da istočasno vidimo vsak nekaj drugega.

Ena (in do sedaj najzanesljivejša) rešitev, kako se izogniti temu kompleksnemu vprašanju, je ta, da se prilagodimo določeni perspektivi, kar poimenuje Husserl normalizacija videnja, iz česar se nato razvijejo institucionalni pomeni, ki bi jim lahko rekli tudi tradicije. Eden izmed takih institucionalnih pomenov je tudi literarni kanon. Vendar pa se je ta $\mathrm{v}$ zadnjih desetletjih znašel $\mathrm{v}$ ambivalentnem položaju, predvsem 
v zahodnih družbah. Kanon, ki je vezan na razumevanje skupnosti nekega naroda in njenega odnosa do drugih skupnosti, je podvržen strogi kritiki že zaradi neupoštevanja (in posledično nerazumevanja) individualizmov in različnih manjših skupnosti znotraj obstoječe skupnosti, ki je ta kanon oblikovala. Vse pogosteje se pojavlja tudi vprašanje o sami smiselnosti kanona. Ali to pomeni tudi konec kulture, kot smo jo poznali do sedaj in $\mathrm{v}$ kateri smo se formirali? Ali moramo zavreči idejo o enem samem kanonu in sprejeti vzporedne kanone, ki jih bodo oblikovale različne kulture in skupnosti s svojimi sistemi vrednot? A kaj takšen razdrobljeni kanon pomeni za majhen narod, kot je slovenski, ki se je vzpostavil prav na podlagi literature? Eden glavnih problemov pisanja literarne zgodovine je (bil) namreč ta, da se ji pripenja različne neliterarne (pragmatične) funkcije, pozablja pa se na to, da lahko literaturo beremo tudi brez neke že vnaprej razvite tendence oziroma instrumentalizacije. Podobno meni tudi Dović:

Vsaka zgodovina $v$ praksi izhaja iz zadovoljevanja neke potrebe in ena najočitnejših takih funkcij zgodovine je bila politična, $v$ devetnajstem in na začetku dvajsetega stoletja večinoma $\mathrm{v}$ zvezi $\mathrm{z}$ narodom in narodno identiteto. $\mathrm{Na}$ podlagi radikalnega konstruktivizma empirična literarna znanost ugotavlja, da je tudi vsaka literarna zgodovina pripovedni konstrukt, ki so mu kavzalnost, teleološkost in podobno od zunaj pripete kategorije (Dović, Sistemske 75).

Položaj literarne zgodovine na Slovenskem je dal veliko misliti že raziskovalcem v zborniku Kako pisati literarno zgodovino danes? (2003), kjer so si bili avtorji precej enotni v tem, da je tradicionalna nacionalna literarna zgodovina zadeva preteklosti, da za literarno zgodovino in literarni kanon ni več nujna distinkcija med visoko in trivialno literaturo in da je besedilo dinamičen proces. Skratka, pojavila se je potreba po različnih literarnih zgodovinah, saj so postajale tudi zahteve bralstva vedno bolj različne. In tudi skoraj dve desetletji kasneje se perspektiva ni spremenila, kot piše Darko Dolinar v monografiji Slovenska literarna veda od Trubarja do druge svetovne vojne (2018):

Osnovno določilo literarne vede je to, da nekaj ve o literaturi in da si čez meje že dane vednosti prizadeva zvedeti o njej nekaj več. Njene različne smeri se določajo predvsem po tem, v kakšna razmerja stopajo z literaturo, pa tudi z drugimi vrstami misli o literaturi. Če (prezgodaj) pristanemo pri neki konkretni opredelitvi in s tem zanikamo vse druge, različne, a ravno tako možne in upravičene, nas lahko hitro zanese predaleč; bolje je ohraniti veljavnost splošnih sklepov o literarni vedi ne glede na njene delitve na smeri in šole (10). 
Model medkulturne literarne vede in pisanja zgodovine izhaja onkraj preprostih binarizmov, kot so lastno/tuje, individualni/kolektivni spomin, centralno/periferno, lokalno/globalno, kar pomeni, da razume identiteto kot dinamično komponento, ki je kulturi imanentna. Po drugi strani pa so večperspektivnost, demokratizem in medkulturnost privedli do problema, ki še dodatno obremeni literarno zgodovino, in sicer izredno povečana literarna produkcija $\mathrm{v}$ zadnjih desetletjih. Literarni zgodovinarji so tu postavljeni pred težko nalogo, kaj izbrati v celotnem naboru, da bo preživelo naš čas. Dobro podlago za tovrstno problematiko omogoča empirična literarna znanost, ki pri prenovi literarne zgodovine upošteva mnogo dejavnikov, ne samo literarnega besedila. S proučevanjem interdisciplinarnosti, njenega družbenega položaja in bralnih procesov (skupaj z bralčevim vrednotenjem) lahko bistveno izboljšamo aktualnost literarne vede in pripomoremo $\mathrm{k}$ (pre) oblikovanju literarnega kanona, ki bo večglasen in bo zajemal duha časa ter upošteval tudi vse obrobne poti, ki bodo na koncu pokazale na kompleksnost našega časa. Ena izmed možnosti aktualizacije literarne vede je prav medkulturna literarna veda, ki misli medkulturnost $\mathrm{v}$ fenomenološko-hermenevtičnem smislu, to pa predstavlja možnost razširitve slovenske literarne vede in znotraj nje predvsem literarne zgodovine $s$ pomočjo medkulturne hermenevtike. Medkulturna hermenevtika odpira možnosti prav za spoznavno-refleksivno funkcijo literature, $s$ tem ko prestopa tla tradicionalne hermenevtike in jo rekonstruira $\mathrm{v}$ smeri spoznavnoteoretskega konstruktivizma, ki spodkopava uniformirano perspektivo ter omogoča večperspektivnost. Tu pa je treba poleg literarne zgodovine omeniti še eno disciplino, ki precej izgublja na svoji funkciji, in sicer literarna kritika. Literarna kritika bi se morala osredotočiti na vrednotenje del tudi na podlagi odzivov (zahtevnejših) bralcev in tu se zdi razlikovanje med trivialno in netrivialno literaturo nujno, saj izpolnjujeta povsem drugačni funkciji: ena hedonistično, druga spoznavno-refleksivno. Tu ne govorimo o hermetično zaprti visoki literaturi, temveč želimo zgolj obuditi fenomenološko-hermenevtično izkušnjo, ki je lastna vsakemu bralcu, ter spodbuditi spoznavno-refleksivno funkcijo pred zgolj hedonistično. Živimo namreč v času, ko knjiga ni več naložba za prihodnost, temveč prej sredstvo za zadovoljitev trenutne potrebe, trenutnega impulza. Knjiga je postala nekakšna modna muha, vprašanje, ki se ob tem poraja, pa je: ali naj pride »hipna« knjiga sploh v kanon in kako naj se literarna zgodovina spopada s hiperprodukcijo. Raziskave in statistike slovenskega knjižnega trga kažejo, da je v Sloveniji več piscev kot bralcev, in že tu se kaže nezmožnost literarne kritike in zgodovine, da bi zaobjeli celotno literarno produkcijo (glej 
Kovač idr., Rupar idr.). Zdi se tudi, da je sodobna književnost razpeta med dva pola: na eni strani imamo besedila, ki tekmujejo s pričakovanji trga (mainstream), na drugi strani pa besedila, ki si prizadevajo za potujitveni učinek, torej za ohranitev literarnosti.

Nova (medkulturna) literarna zgodovina bi tako raziskovala ne le družbeno-kulturne razmere in svojo povezavo s tradicijo, temveč predvsem svoje bistvo - literarnost - v svoji dinamični identiteti ter njen pomen za človekovo bivanje (in delovanje) v svetu. Literarna zgodovina zato ne bi stremela $\mathrm{k}$ enotni zgodbi, temveč $\mathrm{k}$ večperspektivnosti, ki bi odpirala možnost za medkulturni dialog. Prenova literarnozgodovinske paradigme bi bila nekakšna sinteza sistemske teorije in radikalnega konstruktivizma ter sprotne produkcije pomenov ob izkustvu tujega in s samorefleksijo (medkulturna hermenevtika). $\mathrm{V}$ ospredje raziskovalnega besedila bi se tako vrnil bralec kot (kritično) razmišljujoči subjekt $\mathrm{v}$ prostoru in času, $\mathrm{v}$ vedno novih, drugačnih razmerah, kar bi imelo vpliv tudi na identiteto literarnega dela. Empirična literarna znanost, ki ima za svojo teoretsko podlago sistemsko teorijo in radikalni konstruktivizem, se do literature vrednostno ne opredeljuje, zato pridejo v obravnavo vse vrste besedil od visoke do trivialne literature in $\mathrm{v}$ različnih pojavnih oblikah. Radikalni konstruktivizem naj bi prinesel nove koncepte razumevanja, ki naj bi se odmaknili od tradicionalne hermenevtike, češs, da tematizira samo "pravi" pomen besedila in zato izgublja kritičnost. Besedilo ni nosilec smisla, temveč mu je pomen dodeljen glede na določeno komunikacijsko situacijo; vsako spoznanje pa je konstrukt. Konstruktivnost je možna, če obravnavamo branje kot enkratni dogodek, ki prinese vedno nove smisle. Na tem mestu pa dobi ponovno pozornost fenomenologija s svojo metodo »k stvarem samim«, v našem primeru natančneje fenomenologija tujega, ki zahteva produktivno responzivnost po Waldenfelsu, ker $\mathrm{v}$ središče tudi ne postavlja več samega smisla besedila, temveč odgovore, ki jih besedilo od nas izzove. Lažno razumevanje oziroma poenostavljanje tujosti zato ne pride $\mathrm{v}$ poštev, saj izključuje drugačno vrednotenje, obenem pa teži $\mathrm{k}$ univerzalizaciji edine prave interpretacije (ravno tiste, ki se jo očita tradicionalni hermenevtiki). Po drugi strani pa se medkulturna hermenevtika ukvarja ravno s potencialom drugosti literature same, saj je besedilo $\mathrm{v}$ prvi vrsti znakovna tvorba $\mathrm{z}$ estetsko-avtonomno funkcijo. Medkulturno hermenevtiko bi tako lahko razumeli kot nadgradnjo tradicionalne hermenevtike $s$ to razliko, da se ne oklepa absolutnega subjekta, temveč sprejema tudi vse stranpoti, ki jih prinašajo drugi $\mathrm{v}$ relaciji s subjektom. Razprtje vmesnosti, ki je pogoj za medkulturno hermenevtiko, osmišlja medkulturno srečevanje, medkulturna herme- 
nevtika pa pomeni interpretacijo tega srečanja. Tomo Virk pravi, da kolikor smo osredotočeni na srečevanje z drugim in interpretiramo srečevanje in ne samega drugega, s tem ohranjamo njegovo drugost (prim. Virk, Primerjalna 129). Interpretacija srečanja s tujostjo je vedno soočenje z določeno obliko tujosti, ta oblika pa je odvisna od vsakokratnega branja. Ravno zato tudi ne moremo govoriti o besedilu kot zaključeni celoti in ga ne moremo in ne smemo omejiti zgolj na njegovo referenčno funkcijo. Interpretacija je proces, ki je odvisen od dinamične identitete bralca ter njegove dovzetnosti za tujost. Medkulturna hermenevtika se tako na eni strani ukvarja s potencialom drugosti literature, po drugi strani pa z vlogo bralca, ki mu je pri recepciji dodeljena aktivna vloga. Ta aktivna vloga pa je največkrat povezana prav s samorefleksijo lastne perspektive ob izkustvu tujega. Literatura bi morala zato v prvi vrsti služiti kot prostor samorefleksije, ki črpa iz vmesnosti in kaže na najpristnejšo človekovo interakcijo s svetom.

Medkulturnost je bila v zgodovini v slovenskem prostoru ves čas nekakšen modus operandi, le da se ga nihče ni dobro zavedal oziroma se s tem vprašanjem ukvarjal, saj je bilo v ospredju to, da so Slovenci v strahu pred izgubo identitete vse upe polagali v lastno kulturo in literaturo, pri tem pa samo poglabljali njeno referenčno funkcijo. Podobno misel najdemo pri Jančarju:

Novodobna slovenska duhovna, kulturna in v nekem smislu celo politična zgodovina se začne v znamenju izgnanstva. [...] Vsaka ideologija, vsaka ekonomija, vsak demografski sunek od drugod je etnijo razdelil, njen del navezal nase in drugega zavrgel, jo kot celoto razmajal in razredčil. To pa pomeni, da je zgodovina slovenskega eksila tudi zgodovina globoke notranje nesvobode Slovencev. [...] Nobeno zgodovinopisje in nobena statistika ne moreta več izračunati in sešteti količine slovenskega eksila, še manj pa kvalitete njegovega človeškega obsega (Jančar, Terra 39-40).

Ukvarjanje z nacionalnim vprašanjem bi bilo morda bolj plodovito, če bi se osredotočili na ustvarjalnost posameznika. Literatura, ki je Slovencem služila kot nadomestek za nacionalno ideologijo, je bila tako prikrajšana za tisto plat, ki bi lahko ponudila bolj poglobljeno sliko o vprašanju identitete malega naroda. Z analizo različnih refleksij bi lahko pokazala na tisto dogajanje, ki se je odvijalo v najbolj intimni sferi razmišljujočega subjekta, pahnjenega $\mathrm{v}$ določeno (osebnostno) krizo, s tem pa bi se razprl intrasubjektivni medkulturni aspekt slovenske književnosti. 


\section{Spomin: med intra-in intersubjektivnostjo}

Zvrsti, kot so avtobiografija, ${ }^{3}$ dnevnik, pismo, memoari ipd. se preko spomina kažejo kot intrasubjektivna oblika književnosti, kjer je v ospredju razmerje lastno/tuje. V nadaljevanju se bomo posvetili predvsem avtobiografskemu avtoreferencialnemu diskurzu, kjer bomo skušali pokazati, da je meja med dejansko zgodovinsko resničnostjo, individualnim spominom, kolektivnim spominom in konstrukcijo realnosti precej zabrisana. $\mathrm{V}$ prej omenjenih zvrsteh se kaže potreba človeka po nenehnem razumevanju sebe in to je tisto, kar človeka žene $\mathrm{k}$ pripovedovanju in pisanju, saj se mu zdi, da bo lahko s pripovedjo izrekel zadnjo besedo in $s$ tem dobil nadzor nad svojo preteklostjo. A zatakne se že pri samem procesu pisanja, pri katerem črpamo iz spominske shrambe, ki je ne glede na raznolikost, intenzivnost in veličino dogodenega precej omejena in fragmentarna. Človek svojega spomina ne more obvladovati, tako kot ne more obvladovati svojega življenja. Življenje namreč predstavlja nekakšen vseobsegajoči red v vseh svojih razsežnostih oziroma $\mathrm{v}$ dekonstruktivističnem smislu: življenje posameznika zajema vse, kar se je zgodilo, kar bi se lahko zgodilo in kar se bo zgodilo. In ravno zato je za človeka največja tujost prav življenje samo, poskus ubesedovanja vseh njegovih razsežnosti pa lahko postane osrednje pisateljsko vodilo. Realni dogodki se preoblikujejo že v samem procesu spominjanja, ko je meja med realnimi dejstvi in zgodbo že precej zabrisana. Če ponovno vzamemo za primer Jančarja, ki v svoji zbirki popotnih zapiskov in premislekov z naslovom Postaje reflektira ravno to vmesno stanje, ko je pisal in obenem črpal iz svoje spominske shrambe:

Še pisec teh vrstic je moral, preden je napisal te vrstice, kar nekaj dni in noči obujati spomin na mladega pisatelja, že skoraj na nekoga drugega, ki je potoval po državi, ki je ni več, v skupini avtorjev iz države, ki je prav tako ni nikjer več, iz pozabe je skušal iztrgati stavke, ki jih nihče več ne bere. Vse je naenkrat tako daleč v meglicah sanjske pokrajine, Berlin, Dresden, šala s prevajalko, še ironija z bombami, ki padajo na Beograd (186-187).

Podobno refleksijo vmesja najdemo tudi pri Kovačiču: »Med tistim, kar bom napisal, ko razmišljam in hodim po svoji sobi gor in dol, in

${ }^{3} \mathrm{Tu}$ ne gre toliko za avtobiografije v prvotnem pomenu besede, ampak bolj za dela, ki reflektirajo avtobiografsko ozadje, torej vpetost subjekta v sam proces nastajanja besedila. Pri taki obliki avtoreferencialne refleksije se tudi najbolje pokažeta vmesnost, ki se jo reflektira, in zavedanje o krhkosti spomina. Sploh pri Kovačiču gre pogosto za prepletanje avtobiografske snovi in avtoreferencialnosti prav v smislu prej omenjene refleksije procesa pisanja oziroma ustvarjalnega procesa. 
trenutkom, ko primem stol in sedem, da tisto napišem, je to napisano že drugačno« (33; poudarki v originalu).

Kar je bistveno za intrasubjektivni aspekt pisanja, je misliti »sebe kot drugega«, ${ }^{4}$ torej zmožnost zamisliti si, da smo tudi mi zgolj Drugi. Spomin kot refleksijska konstrukcija odpira prostor dialoga s samim sabo, kjer se vzpostavlja narativna identiteta na podoben način kot pri branju. Pri spominjanju pride do dinamičnega odnosa med spominom in pozabo, ravno tako kot pride pri branju do dinamike med bralcem in besedilom. Narativna identiteta po Ricoeurju je namreč vsaka identiteta, ki se vzpostavi skozi posredovanje pripovedi in nastaja ob srečanju z Drugim. Pripovedna identiteta je zato tudi dinamična identiteta, saj je že samo življenje uperjeno proti (pripovedni) fiksaciji. Vsaka pripoved pa je vedno tudi intersubjektivna, saj je vanjo vedno vključen Drugi. Ko pišemo, vedno pišemo za druge; ko pripovedujemo, vedno pripovedujemo drugim. In tudi ko pripovedujemo ali pišemo sebi ali zase, to le pomeni, da sebe dojemamo kot Drugega, kar pa sodi med najvišje stopnje samorefleksije.

A kaj se zares dogaja, ko pišemo in skušamo priklicati spomine? Avtobiografski spomin je zelo krhek, saj spomine, ki jih držimo le zase, jih ne obnavljamo ali preverjamo pri drugih, težko prikličemo, ne da bi jih ob tem že preoblikovali. Avtobiografija, čeprav naj bi bila najbolj intimno in zanesljivo povezana $\mathrm{z}$ avtorjem, je podvržena mnogim dejavnikom: od prilagajanja resnice zavoljo boljše zgodbe in trenutnega stališča interpretacije (tj. naše zgodovinskosti) do prekrivanja s spomini drugih in (nezavednega) prilaščanja spominov drugih kot svojih lastnih. Življenjska pripoved je konstrukcija, spomin in fikcija pa sta si bliže, kot se zdi na prvi pogled. Ko se skušamo sami spomniti nečesa, kar zadeva nas same, kaj kmalu zaidemo v "produktiven dialog"s samim sabo, kjer polnimo bele lise z lastno domišljijo, z lastnimi rešitvami ali z zanašanjem na kolektivni spomin. Spomin namreč ni temelj zavesti, ampak zgolj ena izmed možnih perspektiv zavesti; čistega spomina ni. Je dinamičen in lahko rečemo, da funkcionira podobno kot branje, le $\mathrm{da}$ je spomin usmerjen $\mathrm{v}$ dinamično identiteto, ki prehaja $\mathrm{v}$ preteklost, branje pa v dinamično identiteto, ki prehaja v prihodnost. Oba procesa pa se odvijata s točke tu in zdaj, iz vmesja, ki se nahaja med lastnim in tujim. Oba procesa - tako individualni spomin kot branje - imata sposobnost premeščati in spreminjati dano realnost. Pri spominjanju gre ravno tako za prepoznavanje in razumevanje drugosti, le da smo mi sami

${ }^{4}$ Ricoeurjeva formulacija »sebe kot drugega» pomeni sposobnost dojeti sebe kot eno izmed stvari narave, okolice (glej Ricoeur). 
obenem tudi pripovedovalci oziroma pisci, ki imamo v spominu zapisane določene sheme, in bralci (teh lastnih shem spomina), ki moramo zapolniti prazna (pozabljena) mesta. Tudi pri spominjanju se spopadamo z neko vrsto tujosti, zato je spomin dober primer Freudovega reka, da »nismo gospodarji niti v lastni hiši«. Fragmentarnost in izmuzljivost življenja se namreč izražata $\mathrm{z}$ vsakim trenutkom, ki postane "nezaobjeta" preteklost, tj. preteklost, kateri nismo mogli pripeti določenega smiselnega okvirja. Fragmentarnost življenja, ki se (in verjetno najbolje) odraža tudi $v$ fragmentarnosti literature, je posledica večplastne vpetosti subjekta $\mathrm{v}$ svet. Iz tega lahko zaključimo, da ne bo človek nikoli celovit, čeprav se njegova težnja po obvladovanju svojega življenja kaže v prizadevanju zastaviti svoje življenje kot pripoved. Človekovo ravnanje je namreč uperjeno k nekemu smislu in namenu, kar pomeni, da se ravna proti cilju. Človek si bo vedno prizadeval za pripisovanje smisla in cilja dejanjem ter dogodkom - kar nima konca, namreč tudi nima smisla. Vendar pa identiteta, ki jo človek gradi med pripovedovanjem, ne more biti nikoli zares dokončna, saj gre pri procesu pisanja/pripovedovanja vedno le za raziskovanje (in iskanje) sebe. Kot se svet okoli nas stalno preoblikuje in spreminja, je ravno tako tudi s subjektom in njegovim življenjem. Pisanje (pripovedovanje) zato ne pomeni nič drugega, kot vstopati v tujost odsotnega časa.

Zgodovina, kot jo predlaga Foucault, je nekakšen absolutni pojem, mi pa bi jo z Waldenfelsovo terminologijo ${ }^{5}$ lahko označili kot radikalno tujost. To pomeni, da preteklih dogodkov ne moremo (s)miselno obvladati - ne tistih lastnih, še manj pa tistih, pri katerih sploh nismo bili prisotni. Preteklost kot senca lebdi nad našim spoznavnim redom in je njegova radikalna tujost $\mathrm{v}$ vseh potencialnih, neodkritih, zamolčanih pomenih - kot življenje samo v vsej svoji razsežnosti. Iz tega lahko sklepamo, da pisanje zgodovine ne more biti povsem objektivno, saj je vselej konstrukt, zgolj eden izmed pripetih pomenov. Še bolj pa to velja za pisanje literarne zgodovine, saj literatura že sama po sebi ne teži $\mathrm{k}$ absolutni resnici.

Individualni spomin je konstrukt, ki nastaja $s$ pomočjo lastnega nezanesljivega spomina, pričevanj drugih in domišljijskega polnjenja spominskih lukenj, ko poskušamo spominske fragmente povezati $\mathrm{v}$ smiselno celoto. Zaradi pričevanj drugih in tudi zaradi lastne vpetosti v zgodovinskost je individualni spomin vedno tudi kolektivni spomin.

5 Študije Bernharda Waldenfelsa večinoma obravnavajo teme s področja fenomenologije tujega. Tujost klasificira po treh stopnjah - normalna/vsakdanja, strukturna in radikalna/ekstraordinarna tujost -, ki jih natančno opredeli v knjigi Topographie des Fremden (1997). 
To je tista tanka linija med intrasubjektivno in intersubjektivno ravnjo, saj je lastno vpetost $\mathrm{v}$ svet nemogoče misliti neodvisno od drugih:

Človek je navsezadnje ekstremen produkt vsega, kar imenujemo odvisnost človeka od človeka, ker vseskozi ustvarja človeka po človeku. To ni nikakršna filozofija, samo vizija konkretnosti. Človek je povezan s človekom, človek stremi k človeku, v vsakem trenutku se eden ustvarja pod pritiskom drugega in se oblikuje drugače, kot je hotel, tako da je nemogoče govoriti o fiksnem statistično stanovitnem bitju, ampak bolj o medčloveških "napetostih in prenapetostih", ki vsakogar v slehernem trenutku »determinirajo in definirajo» (za nekaj časa ali kdaj za vselej) (Kovačič 115).

Kolektivni spomin je Jan Assmann razdelil na komunikativnega in kulturnega, kjer je komunikativni spomin nekaj, kar si delimo s (še živečimi) sodobniki (in kamor sodi tudi generacijski spomin), medtem ko je kulturni spomin že nekaj simbolnega, torej zadeva absolutne preteklosti. Halbwachs, ki je razvil koncept kolektivnega spomina, pravi, da individualni spomin ne more niti obstajati in niti funkcionirati brez kolektivnega spomina skupine, katere del je. Okolje posameznika se namreč neprestano spreminja - selitve iz kraja v kraj, hitrejša in pogostejša potovanja, ekonomske migracije, menjavanje krogov prijateljev in sodelavcev ipd. $Z$ vsemi temi menjavami in spremembami izginjajo tudi kolektivni spomini, ki posameznika vežejo na določeno skupino. Zgodi se, da zaradi tega bledi tudi individualni spomin, ki ga je treba zavoljo ohranitve stalno osveževati in usklajevati s spominom ostalih članov skupine, saj lahko le na podlagi tega pretekle dogodke tudi rekonstruiramo. Vse težje se je $s$ kolektivnimi spomini spopadati $\mathrm{v}$ času globalizacije, ko se morajo lokalne razmere prilagajati (ali celo podrejati) globalnim razmeram, ko pride do t. i. glokalizacije in ko je pojem identitete še bolj vprašljiv. Vedno nove identitete in kolektivitete, ki v tem procesu nastajajo, morajo biti še posebej pozorne pri izbiranju spominskih repertoarjev. Literarna zgodovina, ki ima po osamosvojitvi tudi funkcijo krepitve kulturnega spomina, igra zato v slovenskem kulturnem prostoru še vedno pomembno vlogo - kolektivni spomin namreč vzdržuje živo vez med generacijami.

Kulturni spomin je oblika nove kulturne zgodovine, saj se je - kot je ugotovil tudi Peter Burke v Kaj je kulturna zgodovina (2007) - drastično povečalo zanimanje javnosti za zgodovinski spomin, kar je »odziv na vse večjo hitrost družbenih in kulturnih sprememb, ki ogrožajo identitete z ločevanjem tega, kar smo, od tega, kar smo bili« (76). Z vidika literature kot komunikacijskega sistema je literarni kanon poglavitni vzvod za oblikovanje kulturnega spomina, kot je ugotavljal že Assmann, ki 
je dejal, da predstavlja kanon celoto neke družbe in njen vrednostni sistem, v katerega so vključeni posamezniki te družbe in kot njeni člani gradijo identiteto. Burke se je spraševal, "ali bo to, kar prihaja, še bolj radikalno gibanje ali pa bomo, prav nasprotno, priče približevanju bolj tradicionalnim oblikam zgodovine" (116). In meni, da prihodnost ne bo zgolj preprosto nadaljevanje preteklosti, temveč se moramo pripraviti na morebitne poskuse vračanja $v$ preteklost. Ena izmed možnih usmeritev kulturne zgodovine bi bila lahko oživitev zgodovine visoke kulture, kjer zgodovina ljudske kulture verjetno ne bi izginila, bi pa soobstajali obe, s povečanim zanimanjem za njune medsebojne vplive. Za primer poda recepcijo nekaterih velikih kulturnih gibanj pri različnih družbenih skupinah in pravi, da vsak poskus vrnitve v preteklost prinese nekaj novega, kar lahko opazimo pri nekaterih nedavnih poskusih oživitve tradicije, a tudi redefiniranja tradicije kažejo na to (prim. Burke 116-119).

Zavedanje o lastni tradiciji (tudi identiteti) je zato bistveno za ohranitev kulturnega spomina in kolektivne identitete, preko katere se definira tudi vsak posameznik. Za aktivno in medkulturno udejstvovanje $\mathrm{v}$ svetu je torej pomembno, da $\mathrm{v}$ zrelem zavedanju o lastni identiteti izhajamo iz tradicije in jo prenavljamo. $V$ časih zlomljene tradicije, ko se mora človek odločiti, kateremu redu bo sledil in pripadal, pride do ponovne oživitve in zanimanja za tradicijo in kanon ter vzgojo prek njega. V situacijah, ko se moramo odločati med različnimi možnostmi, lahko ponudi kanon najboljšo ali celo edino smer, s tem pa pomaga pri izgradnji ali ponovni (iz)najdbi identitete. Kanon lahko ponudi tudi moralno strukturo, s pomočjo katere se nauči človek ponovno vzpostaviti vrednostni sistem in sistem vrednot. Assmann je definiral kanon kot "princip formacije in stabilizacije identitete, ki je obenem tudi osnova za individualno identiteto in obenem princip nove oblike kulturne koherence« (53). Literarna zgodovina se mora zato dialoško odpirati tako nazaj z refleksijo obstoječega kanona (tradicije) kot tudi naprej v medkulturnem dialogu med tradicijo in njeno prenovo.

\section{Identiteta: med intra-in interdiskurzivnostjo}

Osamosvojitev Slovenije, ki je prinesla dokončno narodno utrjenost in vse pogoje za nadzor tudi nad avtonomnim dogajanjem v literarnem polju, je časovno sovpadla ravno z valom postmoderne, za katero je značilno preseganje dihotomije med visoko in nizko literaturo ter povečano zanimanje tudi za trivialno književnost. Sprva, takoj v času 
osamosvajanja, je s povečanim zanimanjem za raziskovanje preteklosti literarna zgodovina začela upoštevati doslej še neznane in neupoštevane drugosti, ki jih najdemo pretežno na obrobju literarnega polja. Drugačni pogledi na slovensko literarno preteklost na eni strani in zanimanje (ter vključevanje v literarni kanon) za obrobne ter neevropske književnosti na drugi strani so začeli kazati na razvijanje intra- in interkulturne zavesti. Na prvi pogled se je zdelo, da bo vstop na globalni trg še dodatno vzpodbudil večji pretok medkulturnih stikov in izmenjav ter povečal tudi možnost za uveljavljanje obrobnih avtorjev. A zgodilo se je, da so postali centri prevladujoči tudi na globalnem literarnem trgu, kar pa je imelo za posledico tudi uvoženi kulturni kapital. Vse je tudi v veliki meri odvisno od promoviranja v centralnih deželah - če je neko delo dobro sprejeto med kritiki in bralci v določeni centralni deželi, bo imelo večjo možnost za pridobitev sredstev za prevod v jezik periferne dežele, kar zopet potrjuje vlogo centralnih jezikovnih kultur pri kanonizaciji avtorjev. A preden preidemo na razmerje lokalno/ globalno, ki ga bomo poimenovali tudi interdiskurzivna raven medkulturnosti, naj najprej problematiziramo intradiskurzivno raven, kjer si bomo na kratko pogledali razmerje med centralnimi in perifernimi elementi znotraj slovenskega literarnega sistema (tj. diskurza). ${ }^{6}$ Videli bomo, da se tudi znotraj perifernega literarnega sistema, kot je slovenski (če gledamo slovenski literarni sistem na zemljevidu svetovnih literarnih sistemov), vzpostavlja nekakšna hierarhična lestvica. Eden izmed vodilnih perifernih elementov znotraj slovenske književnosti sta izseljenska in priseljenska književnost, s katerim se je ukvarjala Janja Žitnik Serafin v delu Večkulturna Slovenija (2008), ki pravi, da Slovenija močno zaostaja pri kulturni integraciji priseljencev, težišče svoje raziskave pa postavlja v odnos matične kulture do izseljenske in v odnos večinske kulture v Sloveniji do priseljenskih kultur (priseljenci iz delov nekdanje Jugoslavije). Njena raziskava pokaže, da je v Sloveniji od leta 1990 dalje zaznati skokovit porast zanimanja za zdomsko književnost (podobno velja tudi za vključitev zdomske književnosti med temeljna dela slovenske literarne zgodovine) in finančno podporo zdomski revialni publicistiki, medtem ko stanja priseljenske kulture ne opisuje tako zelo rožnato (poleg slabe prepoznavnosti tudi izključenost iz temeljnih del slovenske literarne zgodovine). Prva antologija manjšinske in priseljenske književnosti v Sloveniji je, denimo, izšla šele leta 2014. Avtorji te antologije ustvarjajo v svojem maternem jeziku, in sicer italijanskem, madžarskem, makedonskem, slovaškem, bosanskem,

\footnotetext{
${ }^{6}$ Raba Foucaultovega koncepta diskurza.
} 
hrvaškem, srbskem, romskem in angleškem jeziku. Avtorjev morda ne moremo priznati za slovenske avtorje, če ostanemo pri golem vprašanju jezika, lahko pa jih priznamo kot avtorje slovenske kulture, saj so del slovenske medkulturnosti in lahko ponudijo drugačen pogled na slovenski prostor in njegovo identiteto, $s$ tem pa dodajo medkulturno perspektivo tudi slovenskemu literarnemu kanonu. Medkulturna literarna zgodovina je namreč bistvena tudi za razumevanje lastne kulture. Zakaj? Ce damo na stran vse kulturne, jezikovne in etične razlike, je mogoče migrantski ${ }^{7}$ književnosti določiti tri glavne lastnosti:

(1) Pisci, njihov material in načini pisanja niso tako zelo drugačni, le zahodne kulture se lotevajo iz druge perspektive in očarajo prav $s$ tem pogledom od zunaj. (2) Migrant je danes zanimiva figura zaradi vseh sprememb, ki se pojavljajo v kulturnih obzorjih vsepovsod, ter zato, ker je večina ljudi pod vplivom tako lokalnih kot tudi globalnih sil. Živimo v svetu, kjer smo, če nekoliko karikiramo, vsi nekakšni migranti, ker se je svet zaradi medijev, migracij in sprememb gospodarskega reda tako spremenil. (3) Nazadnje, pisanje migrantov se zdi zelo spretno pri formalni evoluciji, in sicer z uporabo različnih glasov in kombinacij zahodne tradicije in lokalnih literatur (Thomsen 248-249).

Ko mislimo razmerje med centralnim in perifernim, ne moremo mimo Lotmana. Vsaka struktura je sredotežna, kar pomeni, da se vedno opira na nekakšen center, naj bo to (kolektivna) zavest, razum, identiteta, bog ipd. Vedno gre za iskanje središča, ki ga v sami strukturi pravzaprav ni (od koder izhaja tudi Derridajeva dvojica prisotnost/odsotnost). Struktura središča namreč stalno razpada, pri tem pa prihaja do ponovne iznajde določenih struktur oziroma njenih rekonstrukcij. V tem procesu znova lahko najdemo medkulturnost, če izhajamo iz predpostavke, da nobena kultura oziroma struktura ni homogena. Lotman je pokazal, da je razmerje centra in periferije eden najustreznejših načinov, kako razložiti delovanje kulture: samo mejne strukture omogočajo

\footnotetext{
${ }^{7}$ Medkulturna literarna zgodovina kot raziskovalna disciplina medkulturne literarne vede raziskuje odnose med posameznimi nacionalnimi literaturami in vplive, ki so jih te deležne pri različnih literarnih ter kulturnih prenosih. Raziskovalno področje medkulturne literarne zgodovine vključuje tudi tako imenovane medkulturne literature; to so vsa tista besedila, ki tematizirajo in na različne načine obravnavajo kulturne prestope (prestope meja lastne kulture). Sem sodijo postkolonialna literatura, migrantska literatura, manjšinska književnost in pa izseljenska književnost. Pri medkulturni književnosti gre predvsem za dela avtorjev etničnih manjšin. Izraz medkulturna književnost je v tem kontekstu še relativno nov. Izrazi, ki se uporabljajo za literature avtorjev, ki pripadajo določeni kulturni manjšini, so številni in raznoliki - od zdomske, migrantske in migracijske književnosti do književnosti v medkulturnem stiku, medkulturne literature, inozemske književnosti ipd. (prim. Leskovec, Einführung 18).
} 
prehajanje tujega prostora $\mathrm{v}$ semiosfero. Semiotični procesi potekajo na periferiji kulturne sfere, ti procesi pa so za razliko od procesov $\mathrm{v}$ jedru bolj dinamični. Razmerje med centri in periferijo se zato stalno spreminja, saj se $\mathrm{z}$ vdorom tujega $\mathrm{v}$ obstoječi semiotični prostor pojavi nov, drugačen prostor. Center, ki se ima mnogokrat za jedro napredka in inovativnosti, pozablja, da se vsaka inovacija sprva znajde na robu sistema, nato postopoma prehaja do centra, vmes pa se staplja $s$ tradicijo ter jo prenavlja (rekonstruira). V centru se nato nakopiči prečiščena oblika tujosti (novosti), ki prenovi temelje centralnega delovanja sistema. Periferija je torej tista, ki prinaša drugačno videnje ter na podlagi tega tudi nova dognanja.

Lotmanov princip lahko preslikamo tudi na literarno zgodovino: ob upoštevanju perifernih prostorov lahko literarno zgodovino in kanon obogatimo z vsemi prezrtimi platmi. Kot je predlagal že Virk v prispevku z naslovom »Aporije literarne zgodovine danes", temeljijo najperspektivnejše oblike literarne zgodovine na dialektiki kontinuitete in diskontinuitete, kar bi lahko bila Kosova Primerjalna zgodovina. Inovacija namreč vedno izhaja iz tradicije, ki jo prenavlja, kar pomeni, da lahko novo perspektivo opredelimo le na podlagi že obstoječe tradicije, saj v njej vedno že smo in se iz nje odpiramo. Nova perspektiva se nato počasi sedimentira, kar po Lotmanu pomeni postopno prehajanje novih dognanj v zgodovinskost kulturnega spomina. Tam, kjer je literatura v kulturnem spominu igrala (in še vedno igra) pomembno vlogo, se vezi s tradicijo enostavno ne da in tudi ne sme pretrgati. Tu želimo opozoriti predvsem na morebitne pasti literarne globalizacije, in sicer da bi se oblikovalo povsem novo bralno občinstvo, ki bi segalo čez okvirje nacionalne književnosti. Ob tem se ne bi spremenila le družbena funkcija literature, ki bi predstavljala poenotenje literarnega okusa, temveč bi se zmanjšala ali pa celo izgubila sama tujost literature, tj. njena literarnost. Zato je še toliko pomembneje, da mislimo medkulturno perspektivo, ki zajema prav to refleksijo lastnega položaja. Zdravorazumska dinamika med centrom in periferijo (in samorefleksija) se kaže tudi v tem, da znamo opaziti šibkosti prevladujoče paradigme in opozoriti na hegemonijo, ko se ta začne povzdigovati $\mathrm{v}$ neko vsesplošno določilo. To pa pomeni, da perifernih sistemov ne označujemo kot zastarele, centre pa povzdigujemo v edine nosilce smisla. Pred nami se riše precej kompleksnejša slika družbe, ozaveščanje kompleksnih situacij, ki jih izrisuje svet okoli nas, pa pomeni prestop čez dihotomije, kot sta denimo center in periferija. Prednost trenutnega duha časa je ta, da se to dogaja zdaj in da še ni vzpostavljen noben kanon, zato je treba tudi kompleksnost obravnavati drugače. Prihodnost literarne zgodovine in 
posledično kanona kot dela svetovne književnosti lahko vidimo prav v medkulturnosti, saj gre tu bolj za spremembo načina poučevanja in vrednotenja literature, kot pa za nabor izbranih literarnih del. Podobne misli najdemo tudi pri drugih raziskovalcih:

Prepričan sem, da bi morali zavreči tako toge nacionalne kanone, ki narekujejo programe mnogim evropskim izobraževalnim ustanovam, kot tudi poskuse, da bi predlagali, oziroma vsiljevali, univerzalni, oziroma zahodni, kanon literarnih mojstrovin, kot je to predlagal Harold Bloom. [...] V našem Zemljevidu evropske književnosti zato predlagamo nekakšno »evropsko knjižnico«, okvirne sezname knjig, ki se navezujejo na tematike, vsebovane v delu, izbrane po našem okusu in preferencah, odprte za vse možne dodatke in dopolnitve, bralcu pa ponujene v obliki odprtih polic knjižnice, razporejene po tematikah in različnih interesnih področjih (Ceserani 178-179).

Malo prej smo omenili poenotenje literarnega okusa: premik h globalni družbi ima velik vpliv tudi na pisatelje, kar se kaže v podobnosti in "univerzalnosti« tem piscev po svetu. Poleg tega imamo danes tolikšen dostop do literature, kot ga nismo imeli nikoli do sedaj, še vedno pa ostaja mnogo omejitev pri enakomernem kroženju literature. Kljub spremenjeni družbeni paradigmi je tudi sodobni pojem glokalizacije, ki se osredotoča na priznavanje različnih kolektivnih identitet, podvržen asimetriji moči. Pri mnogih obrobnih piscih je tudi moč zaznati "komercializacijo", saj imajo občutek, da morajo zavoljo večje prepoznavnosti in večje distribucije pisati za izvozni trg. $S$ tem se seveda izgubljata tujost in specifičnost literature, tj. literarnost, ki sta neposredno povezani z maternim jezikom, v katerem avtor misli, čuti, doživlja. Komercializacija je $\mathrm{v}$ nekaterih primerih povezana celo $s$ tem, da se pisci na pobudo založnikov odpovedujejo pisanju v maternem jeziku, kar pa lahko privede do opustošenja besedilnega sveta.

Drugi element, ki kroji usodo slovenskega kanona in že prehaja na interdiskurzivno raven in ki smo ga osvetlili že uvodoma, pa je trenutni položaj pisatelja, ki ga je Dović klasificiral kot "pisatelj med umetnikom in proizvajalcem«. Pisatelj se namreč znajde na meji med avtonomnostjo literature in povpraševanjem trga, kjer prihaja do zmanjševanja proračunskih sredstev za kulturo in do kapitalističnega modela založništva, ki daje kvantiteti izdajanja knjig prednost pred kvaliteto. Projekt, ki ga izvaja raziskovalna skupina poznavalcev slovenskega knjižnega trga in založništva, je v predzadnjih raziskovalnih izsledkih, ki so izšli v knjižni raziskavi Knjiga in bralci V: bralna kultura in nakupovanje knjig $v$ Sloveniji, prinesel med drugimi tudi ugotovitev, da se knjiga "vse bolj premika iz medija intelektualnega izziva v medij zabave [, kar 
je] morda dobra novica za knjižno industrijo, nemara pa slabša za kulturno politiko« (41). Seznam najbolj branih ali prodajanih knjig ima večkrat prednost pred strokovno kritiko ali nagrado. V zadnji raziskavi Knjiga in bralci VI, ki velja za leto 2019, pa so ugotovili, da Slovenija nima nekega skupnega branja, saj se vedno bolj vključuje v globalno skupnost, kjer se pretežno bere $\mathrm{v}$ angleškem jeziku. Blatnik piše, da je postalo založništvo povsem gospodarska dejavnost, "v medijih [se] išče predvsem zabavo in novice o družbeni realnosti [se] spremlja površno, ne da bi preverili njihovo verodostojnost. $V$ takih okoliščinah je resno ogrožena svoboda misli, brez svobode misli pa je svoboda izražanja brez vrednosti« (Rupar idr. 50). Bralna dejavnost upada, prodaja knjig, ki je nekoč veljala za strokovno dejavnost, se spreminja v drugorazredni hobi, strokovne literarne kritike pa so zamenjali literarni blogi in število zvezdic na spletnih straneh multinacionalk. Problem današnjega časa pa je tudi ta, da enostavno nimamo in niti ne moremo pričakovati enotnega kriterija, na podlagi katerega bi smeli soditi o kvaliteti literarnega dela. Ravno $\mathrm{v}$ ta namen bi morali strogo ločiti med globalno in svetovno književnostjo, kjer zadeva prva splošno (mainstream) bralstvo uspešnic, druga pa ima še vedno neko vrednost $\mathrm{v}$ smislu kritičnega pogleda na literaturo in oblikovanju kanona. In tu se zdi bistveno, da ločujemo tudi med hedonistično in spoznavno-refleksivno vlogo literature. Slednja namreč govori v prid temu, da se literaturi vrne tisto primarno vlogo, ki bo pomaknila na stran tako politično-ideološke kot tudi ekonomsko-politične tendence ter obudila kar malce zanemarjeno fenomenološko-hermenevtično podstat. To pa pomeni, da bo kot tujost nagovarjala bralca od znotraj, on pa bo lahko zaradi tega bolje deloval tudi navzven. In čeprav se trenutno zdi, da nam pri obvladovanju količine vsega napisanega ne moreta pomagati niti literarna zgodovina niti kritika, pa nam morda lahko pomaga ravno ta razmislek: vedeti moramo, kdo smo kot ljudje, kdo so naši predniki, in poznati moramo zgodbe, ki so nam jih pripovedovali, da jih lahko iz skupne medkulturne zapuščine delimo naprej. Zato je pomembno, da začnemo medkulturno literarno zgodovino graditi na intrasubjektivni ravni, ki je neločljivo povezava z intersubjektivno, ta pa vedno vključuje pogled Drugega, naj bo to pogled sebe kot drugega, pogled na drugega ali tuji pogled. In morda gre prav $\mathrm{v}$ tej smeri iskati tudi tisto vrednost literature, ki jo ima lahko ta sama po sebi. 


\section{LITERATURA}

Assmann, Jan. Das kulturelle Gedächtnis: Schrift, Erinnerung und politische Identität in frühen Hochkulturen. München: C.H. Beck, 2002.

Burke, Peter. Kaj je kulturna zgodovina. Prev. Matjaž Šprajc. Ljubljana: Založba Sophia, 2007.

Ceserani, Remo. "Drawing a Map of a Literary History of Europe«. Studying Transcultural Literary History. Ur. Gunilla Lindberg-Wada. Berlin; New York: Walter de Gruyter, 2006. 169-179.

Dolinar, Darko. Slovenska literarna veda od Trubarja do druge svetovne vojne. Ljubljana: Založba ZRC, ZRC SAZU, 2018.

Dolinar, Darko, in Marko Juvan, ur. Kako pisati literarno zgodovino danes?. Ljubljana: Založba ZRC, ZRC SAZU, 2003

Dović, Marijan. Sistemske in empirične obravnave literature. Ljubljana: Založba ZRC, ZRC SAZU, 2004.

Dović, Marijan. Slovenski pisatelj. Ljubljana: Založba ZRC, ZRC SAZU, 2007.

Halbwachs, Maurice. Kolektivni spomin. Prev. Drago B. Rotar. Ljubljana: Studia humanitatis, 2001.

Jančar, Drago. Postaje. Ljubljana: Cankarjeva založba, 2018.

Jančar, Drago. Terra incognita. Celovec: Založba Wieser, 1989.

Kos, Janko. Primerjalna zgodovina slovenske literature. Ljubljana: Mladinska knjiga, 2001.

Kovač, Miha idr. Knjiga in bralci V: bralna kultura in nakupovanje knjig v Sloveniji. Ljubljana: UMco, 2015.

Kovačič, Lojze. Kristalni čas. Ljubljana: Beletrina, 2016.

Leskovec, Andrea. Einführung in die interkulturelle Literaturwissenschaft. Darmstadt: WBG, 2011

Lotman, Jurij M. Kultur und Explosion. Prev. Dorothea Trottenberg. Berlin: Suhrkamp Verlag, 2010.

Ricoeur, Paul. Sebe kot drugega. Prev. Nastja Skrušny Babin. Ljubljana: KUD Apokalipsa, 2011.

Rupar, Patricia et al. Knjiga in bralci VI: bralna kultura in nakupovanje knjig v Sloveniji $v$ letu 2019. Ljubljana: UMco, 2019.

Thomsen, Mads Rosendahl: »Migrant Writers and Cosmopolitan Readers«. Studying Transcultural Literary History. Ur. Gunilla Lindberg-Wada. Berlin; New York: Walter de Gruyter, 2006. 244-250.

Virk, Tomo. »Aporije literarne zgodovine danes«. Slavistična revija 54.4 (2006): 811829.

Virk, Tomo. Primerjalna književnost na prelomu tisočletja: kritični pregled. Ljubljana: Založba ZRC, ZRC SAZU, 2007.

Waldenfels, Bernhard. Topographie des Fremden. Frankfurt am Main: Suhrkamp Verlag, 1997.

Waldenfels, Bernhard. Vielstimmigkeit der Rede. Frankfurt am Main: Suhrkamp Verlag, 1999.

Žitnik Serafin, Janja. Večkulturna Slovenija: položaj migrantske književnosti in kulture v slovenskem prostoru. Ljubljana: Založba ZRC, ZRC SAZU, 2008. 


\section{Thinking Intercultural Literary History in Slovenia}

Key words: literary history / interculturalism / literary canon / cultural memory / cultural identity / the alien / tradition / globalization

This contribution addresses interculturalism as an issue of literatures in intraand intersubjective as well as in inter- and interdiscursive contact, while also shedding light on some possibilities for expanding Slovenian literary history and its canon. It focuses on the after independence era, when on the one hand there was an increased interest in exploring the past, and on the other, the directions of a homogeneously oriented (global) book market were beginning to emerge. After independence, Slovenia is still facing two turning points: how to maintain its identity, which at the time was completely in the hands of state autonomy; and how a small nation and a small literature to be visible after the fall into the rapidly growing global book market. Based on the model of intercultural literary science, one can see how the self and the alien interweave at all levels of human action, and what impact this has on the construction of a dynamic identity and a dynamic literary canon.

1.01 Izvirni znanstveni članek / Original scientific article

UDK 82.0

DOI: https://doi.org/10.3986/pkn.v43.i3.09 